\title{
LIBERTY AND LAW INSTITUTIONAL CIRCUMSTANCES OF FREEDOM
}

\section{Lena Halldenius}

My aim in this article is twofold. I will discuss different ways of conceptualising the relation between liberty and law. By 'law' I refer throughout to law in the sense of civil law: rules with accompanying sanctions, promulgated by a legislator for the regulation of action in political society. I do not intend to say anything about 'natural law', unless I explicitly state otherwise. For the purposes of my argument I will loosely group the positions I discuss under different labels: 'liberty from the law', 'liberty by the law', and 'liberty under law'. There is nothing self-serving about these labels; indeed, they may appear simplistic and historically inept. I use them to direct our attention and in order to illustrate my second aim, which is to make a fairly general point that seems to me to fall out of the preceding discussion. That point is that concepts like liberty are institution dependent and that we cannot hope to understand or even talk about what they mean without adhering to that fact. I will argue that even when liberty is understood in terms of the absence of law, the presence of law or the possibility of its presence will have to be assumed in principle in order for its absence to make sense. Freedom from law refers to different kinds of absences, depending on whether the law that is not there is the institution itself or an instance of regulation within an institution that is present. ${ }^{1}$ 


\section{LIBERTY AND LAW}

\section{Liberty from the law and liberty by the law}

In one of his Letters to the Spanish People Jeremy Bentham said: 'Mistake me not, my friends, so far as to suppose me passing condemnation on a law, as some have done, on no other ground than that of its being a restraint upon individual liberty: it is only by being such, that laws can be laws.' (Bentham, 1843. My italics.) What Bentham is saying is that laws necessarily restrain liberty. Indeed, the fact that they do is why we have them and anything that does not is not a law. In Leviathan Thomas Hobbes says, famously, that liberty 'depend on the silence of the laws' (Leviathan $\mathrm{ch}$. xxi 18). ${ }^{2}$ If there is a law regulating a certain area of life, my liberty in that area of life is to a corresponding degree restricted.

Contrast these two passages with John Locke's claim in the Second Treatise of Government that 'the end of Law is not to abolish or restrain, but to preserve and enlarge Freedom: For in all the states of created beings capable of Laws, where there is no Law, there is no freedom' (Second Treatise $\$ 57) .^{3}$

What we may term the Hobbes-Bentham-position and the Lockean position respectively correspond to the formulas 'liberty from the law' and 'liberty by the law'. ${ }^{4}$ These labels are underdetermined, as I hope to show, and serves a function mainly by directing our attention, not by providing many pertinent answers in themselves.

'Liberty from the law' would imply that a feature inherent to law is that it constrains liberty. 'Liberty by the law' implies instead that liberty is secured through law; a feature inherent to law is that it protects, or at least is capable of protecting liberty as long as it satisfies certain conditions.

This needs to be unpacked. We should start by noting that these contrasting views do not depend on different ideas about what law is. Law here means properly promulgated rules, made and enforced by the proper authority (even though opinions differ on the proper criteria for identifying such an authority). There is a difference in emphasis when it comes to law, a difference that needs to be understood by considering what the notion of liberty does in the theories in which it appears. One way of putting it is to say that diverging ideas about how liberty is or should be understood make for significant differences not only in how to identify free and unfree individuals, but also in the characterisation of political society, of the state we are in. Another 


\section{LENA HALLDENIUS}

way of putting it is to reverse the perspectives and say that different ways of characterising political society and its institutions partly explains why a certain understanding of liberty appears compelling.

The understanding of liberty implied in 'liberty from the law' is as an area of unimpeded action. Law restricts liberty because it is a restraint on what I may do; it works as an external constraint on individual action. Thus far the terms used - 'impediment', 'constraint', and 'may' - are ambiguous. They can refer to a physical obstacle, making an action physically impossible or difficult to perform, or to less tangible but quite possibly equally disabling obstacles in the form of threats or sanctions that change the desirability albeit not the possibility of performing. Law, it would seem, qualifies as an obstacle of the second sort. The extent to which we enjoy liberty in our capacity as members of political society is the extent to which our lives are unregulated by law. The difference between understanding liberty as the absence of external factors that would affect the possibility of performing (or abstaining) and the absence of factors that would affect the desirability of performing (or abstaining) is illustrated by Hobbes. Liberty in 'the proper signification' is the absence of factual opposition (walls and chains) whereas the liberty of subjects in commonwealth relates to those 'artificial chains, called civil laws'. The bonds of law hold 'by the danger (though not by the difficulty) of breaking them. ${ }^{5}$ When Hobbes says that liberty depends on the silence of the laws and that in 'cases where the sovereign has prescribed no rule, there the subject hath the liberty to do or forbear, according to his own discretion' (Leviathan ch. xxi 18) he refers to but one aspect of liberty, that which presupposes the existence of the institution of law for the absence of its chain in a particular instance to count as an absence significant for liberty.

On this understanding of the relation between liberty and law, the emphasis when it comes to law is on regulation of behaviour; by threat of sanction law is capable of making me do or refrain from doing certain things whatever my will is and by that force settle matters of conflict.

Talking of 'liberty by the law' implies that the extent to which we enjoy liberty as members of political society is the extent to which there is law to secure it. Here the presence of law is not presupposed in order to make the absence of it in particular instances significant for liberty. Law liberates through its presence. It is an ambiguous formu- 


\section{LIBERTY AND LAW}

la, leaving room for at least two quite different conceptions of liberty being expressed by it with corresponding differences in the emphases on law, and we need to address this ambiguity.

Rousseau is notorious for saying that a person may be forced to be free (The Social Contract Book I Ch. 7.) Importantly, Rousseau believed this to be so only in a republic, where the people is both sovereign and subject and the law is an expression of the general will (which, to put it crudely, is another way of saying that it is just). When just law is enforced in the republic, people are freed by force through being secured 'against all personal dependence', i.e. dependence on appetite and desire. To be governed by appetite is slavery; to be governed by just law is to be master of oneself (The Social Contract Book I Ch. 8). Man in political society acquires 'liberty by the law' in two ways. He enjoys civil liberty by having just law as his rule; he is constrained by the general will only, not by the actual will of another. ${ }^{6} \mathrm{He}$ also acquires moral liberty - which is indistinguishable from virtue - since just law forces him to fulfil his potential as a moral agent. The law of the republic enforces man's own choice to convert his unbounded natural freedom into civil and moral liberty. To be a good citizen of a just republic is to be a free citizen, and vice versa.

Rousseau's enlightened self-mastery by law is 'positive liberty' in Isaiah Berlin's sense. ${ }^{7}$ Interestingly, this is consistent with the same emphasis when it comes to law as in 'liberty from the law' - law understood as a chain - but a chain that, given the right constitution, serves the moral purpose, in addition to the regulation of human interaction in society, of propelling the individual towards his moral potential. Moral liberty is violated not by external factors but by my own irrational impulses. The presence of law, still conceived as a chain, now liberates because of a particular conception of the moral purpose of political society.

Liberation through the presence of law can, however, rest on a different conception of liberty and a corresponding difference in the emphasis of law, and this will be my chief concern. Locke is a representative of this other position, as are Mary Wollstonecraft and others. ${ }^{8}$ Law is a precondition of liberty in political society because, in Locke's words, 'Freedom of Men under Government, is, to have a standing Rule to live by, common to every one of that Society' (Second Treatise $\S 22$ ) including the ruler himself. The enjoyment of liberty can here be phrased in terms of an absence, which would make it qualify as 'nega- 


\section{LENA HALLDENIUS}

tive liberty' in the Berlinian dichotomy. That, however, only serves to obscure what is distinctive about this view. The absence significant for liberty is not an absence of obstacles or binding rules, but of the uncertainty of being subjected to the arbitrary will of another. Only through law are we independent, not from our own appetites, but from 'the inconstant, uncertain, unknown, Arbitrary Will of another Man' (ibid.). For Hobbes where law and impediment end freedom begins. For Locke 'Where-ever Law ends, Tyranny begins' (Second Treatise $\$ 202)$.

Unlike Rousseau but like Hobbes, Locke holds that my liberty as a member of society can be infringed only from outside of myself. The difference is that I lose my liberty simply through living in the state of uncertainty that comes from being subject to someone who might interfere with me, on a whim, even if they never do. 'For who could be free, when every other Man's Humour might domineer over him?' (Second Treatise §57). The condition is that the law serves the purpose of political society: to preserve the public good as set out by natural morality. Lockean freedom from dependence on the arbitrary will of another is indeed negative, but demands the absence not of interference, but of arbitrary subjection. ${ }^{9}$

Note again that we need not assume a difference in the meaning of law between what we may crudely term the Hobbesian and the Lockean position. They can agree that law is capable of making me - by threat of force - do or refrain from doing certain things whatever my will is and as a matter of force settle issues of conflict. They can agree that the rule of law is distinctive in that it entails publicly promulgated standing rules and that law for its validity depends on some or other conception of the public good. The divergent conceptions of liberty direct the emphasis to different aspects of one and the same sense of law. If liberty in political society is understood as the absence of arbitrary subjection it is the fact that the law provides standing rules, publicly accessible and checked for validity by the public good (however defined) that makes it true to say that law liberates. Here the emphasis is not on law as restriction, a chain, but as direction, towards a goal to which both ruler and ruled are morally committed. ${ }^{10}$ If liberty in political society is understood as the absence of an obligation to act in any particular way, then the fact that law coerces behaviour is what makes it true to say that law restrains liberty. At no time is the meaning of law under dispute. What is under dispute 


\section{LIBERTY AND LAW}

is the relevant sense of liberty with corresponding differences in the emphases on law's function given the role of law in relation to the purpose of political society.

\section{Authority and forms of rule}

One interesting aspect of this is the implication of the relation between liberty and law for the authority of government, and by extension, to matters constitutional and forms of rule.

Let us start with liberty understood in the Lockean sense as the absence of arbitrary subjection. Understanding liberty in this way was of course fairly common among thinkers with a republican inclination. I have mentioned Mary Wollstonecraft as an example; Richard Price would be another. Here the criterion for legitimate government and the validity of law is found in the conception of liberty itself.

As Locke puts it, political power is 'a Right of making Laws with Penalties of Death, and consequently all less Penalties, for the Regulating and Preserving of Property, and of employing the force of the Community, in the Execution of such Laws, and in the defence of the Common-wealth from Foreign Injury, and all this only for the Publick Good' (Second Treatise § 3). Two things should be noted. First, political power is not the capacity of making and enforcing laws; it is the right of making and enforcing laws. Consequently, political power is per definition legitimate. 'Political' is a normative concept here; illegitimate power is not political. Second, the specific ends of political power are included in the definition of what political power is, and consequently in the criteria for when power is legitimate and when law is valid and binding. ${ }^{11}$

The right to liberty requires the absence of arbitrary subjection. Arbitrary power is coercive in the specific sense of being unchecked by the good of the people, which is the same as the rights derived from natural morality. A ruler that transcends its strictures is not legitimate, its power not political. So the definition of what liberty in political society is provides the criterion for when power is legitimate and when law is binding.

Mary Wollstonecraft's position is similar in structure. Importantly though, she conceptualises the people as stratified, with internal power inequalities which are a political concern. Indeed, the right to 


\section{LENA HALLDENIUS}

liberty of each member of political society is violated by power imbalances among the members. 'Nature having made men unequal, by giving stronger bodily and mental powers to one than to another, the end of government ought to be, to destroy this inequality by protecting the weak.' (Wollstonecraft The French Revolution 1989 p. 17).${ }^{12}$ This means that for Wollstonecraft, as for Locke, political power naturally has a specific set of moral ends - the protection of the birthright of each through the countering of natural inequality - and is justified through the promotion of these ends: 'political associations are intended only for the preservation of the natural and imprescriptible rights of man' (The French Revolution 1989 p. 221) and the birthright of man is liberty. ${ }^{13}$ Liberty, understood as the negation of social relations of subjugation and dominance is a political goal; its promotion is a necessary condition for the legitimation of political action. ${ }^{14}$ When the law fails this standard " the duty lies in the breach and not in the observance.'" (The French Revolution 1989 p. 58).

On Wollstonecraft's account, political rule cannot be legitimate unless it satisfies a certain form. Liberty can only be preserved under a republican constitution, where the people are enfranchised citizens capable of holding the government accountable through their representatives. ${ }^{15}$ Since Wollstonecraft regards the people as stratified into strong and weak, the ends of government requires that 'the weak' have their own representatives, in order to secure their independence from the will of the strong. This is the rationale behind her argument for the enfranchisement of women and the working classes. ${ }^{16}$

If liberty in political society is understood as the absence of law and the emphasis is on law as a restraining chain, there is, from the standpoint of sheer liberty infringement, no difference between laws made and enforced by an absolute monarch and laws made and enforced within a popular democracy or any other form of government that for whatever reason carries authority. Whatever counts as law restricts liberty, because whatever counts as law obligates us to act in one way rather than another. If we wish to assess the worth of different constitutional arrangements we need to do so on the basis of something else, like security, or levels of wealth or patterns of distribution, all regarded as extrinsic to liberty. ${ }^{17}$

Consequently, any political order regarded as legitimate will be so despite the liberty loss it inevitably entails, or possibly because of it, if the absence of restraint is regarded as a source of misery and 


\section{LIBERTY AND LAW}

fear. In Berlin's words: An 'absolute loss of liberty [...] may be compensated for by a gain in justice or in happiness or in peace, but the loss remains' (Berlin 1969 p. 125). The criterion for law being valid and binding will be found in the specification of this compensation, which, it is assumed, people have rational reason to prefer. The point at which law fails to obligate is when it fails to bring the appropriate compensation (to a sufficient degree). For Hobbes, the compensation is effective protection from the fears, threats, and violence of an unregulated state. Hence, the subjects are absolved from obligation to the extent law runs foul of the purpose for which the commonwealth was set up: preservation through peace, and peace is per definition institutionally guaranteed by a common power. ${ }^{18}$

On this approach there is reason to prefer one form of government to another only to the extent the form of government is believed to affect its capacity as a reliable provider of the compensating value. If the compensating value is peace, and if we have reason to believe that a representative democracy with separation of powers is the most reliable upholder of peace, then we have an indirect and contingent reason to prefer this form of government. (We would then also have a reason to say that Hobbes made a mistaken inference from commitment to peace to support for absolute and unitary rule.)

\section{Liberty under law}

At this point I will introduce a third way - historically significant as well as philosophically seductive - of conceptualising the relation between liberty and law, a way meant to lend direct and non-contingent support to republican forms of government without relying on the Lockean notion of liberty in political society and without emphasizing law as direction. The idea is that there can be law, with the emphasis on law as restriction, without liberty loss, not because law liberates but because it is possible to be obligated to law and free in relation to it at the same time. We find this expressed in the political theory of Immanuel Kant and we may call it 'liberty under law'.

A consistent Hobbesian would, of course, say that this is nonsense: To be obligated to law is to be unfree in relation to law because that is what obligation means. To be obligated and free at the same time in relation to the same thing is a contradiction. Again, the disagreement 


\section{LENA HALLDENIUS}

is not over the meaning of law. Hobbes and Kant both define law as a binding command. But neither does it hinge on a difference in the conception of political freedom. Instead, it depends on the notion of the will and on what it means to act voluntarily.

For Hobbes, it is not possible to do anything other than acting on desire. Whenever I act, I act on the last desire in a process of deliberation. The will is not a desire of a particular kind, say a rational or enlightened or well-informed one. The will is simply the name given to that desire on which we act (Leviathan $\mathrm{ch}$. vi 53). Therefore, unintuitive as it may sound, there is no such thing as involuntary action, undertaken for misconceived or coerced reasons, as opposed to voluntary action, undertaken for enlightened or rational reasons. There is simply action, and all action is voluntary, due to his definition of the will. This is why Hobbes can say that subjection to law is voluntary and hence binding ${ }^{19}$ even if submission is motivated by fear. On his definition of voluntariness there can be no such thing as an involuntary act. If I submit out of fear it must be the case that I desire the alternatives to submission even less, or I would not have submitted.

For Kant, the will is the same as practical reason, the capacity to act on principle. ${ }^{20}$ In other words, to act on will is to act independently of a particular desire, exactly that which on Hobbes's notion of the will is nonsense. Acting on will is acting on reason. And the only form of government to which an agent could willingly submit is a representative system, the pure republic. The reason for this being that only in a republic - where I, through my representatives, set the law that binds me - is my status as autonomous - as an agent acting on will - retained.

A 'pure republic' is the only form of government that in Kant's words, 'makes freedom the principle and indeed the condition for any exercise of coercion' (The Metaphysics of Morals. The Doctrine of Right 1996 § 52). This is different from the Lockean position. Here law does not liberate, nor does it serve to direct me towards a common goal; it coerces me in my capacity as a creature of desire. As for Hobbes, it is an absolutely binding command, an artificial chain. But contrary to the Hobbesian claim I remain completely free, in my capacity as an autonomous agent, as long as I myself am the source of my restraint. I am that source only in a republican constitution where, as a member of the law-making sovereign people I make the law that obligates me. In that sense I remain, under law, as free as before. In fact, for Kant the freedom of a moral agent consists in being obligated to law alone. 


\section{LIBERTY AND LAW}

We need to be clear on the subtleties here. Hobbes would also say that the people act whenever the legislator acts since they have authored the sovereign's power through their original act of submission, but by that act of submission they have given up their natural liberty to be guided only by their own will. Here is a third aspect of Hobbes' theory of liberty - in addition to liberty 'in the proper signification of the term', that is, the absence of external impediment, and to the liberty of subjects with obtain only in the commonwealth and on condition of the existence of law as an institution. Natural liberty obtains only in the state of nature - where there is no sovereign - and is the complete absence of that institution the presence of which makes the liberty of subjects make sense. Hence, in the commonwealth there is per definition no natural liberty and the pockets of non-restraint that make up the liberty of subjects do not belie the general obligation in which they stand to the institution of law as such. So the presence of law eradicates liberty in two different ways. Its presence as an institution is what makes natural liberty null and void. Its presence in particular instances is what makes the liberty of subjects - which is predicated on the absence of natural liberty - null. At no time can there be law and liberty (in either sense) at the same time in relation to the same thing.

For Kant it is possible to be free under law while being coerced by it because of the distinction he makes between two aspects of agency, one connected to will and one to desire. It is precisely this type of distinction Hobbes declares absurd, and that is why Hobbes is bound to say that even though we submit to law willingly, the effect of our submission is that we renounce completely our status as free in relation to law.

\section{Liberty and institutional circumstances}

We have identified three types of position on the relation between liberty and law: The Lockean 'liberty by the law' where I am made free by law on condition that the law satisfies certain criteria of justice; Hobbesian 'liberty from the law', according to which law as regulator of behaviour negates the liberty of subjects and the very existence of it as an institution negates natural liberty. And finally, in the Kantian middle-ground - 'liberty under law' - law coerces me and restrains my 


\section{LENA HALLDENIUS}

liberty in my capacity as creature of desire while, in my capacity as an autonomous agent acting on will, I remain as free as before. None of these distinctions hinges on a difference in the meaning of law. The difference between the first two hinges on a difference in the understanding of what liberty is. The difference between the last two hinges on the definition of will and the notion of agency. But importantly, we cannot properly articulate the differences between these positions without attending to the role played by liberty in relation to the institution of law within a theory of the purpose of political society.

I will pick up a few threads of what I have said in order to illustrate a point that I have tried to make throughout this discussion, that liberty is institution dependent, that we cannot understand what it is supposed to mean and what a violation of it is, without adhering to the role it is made to play within a theory of a just society, or legitimate rule or institutional reality. This truly is a lesson from history for present day thinkers on liberty. Most philosophers of the 17th and 18th centuries made some use of a distinction between natural liberty and liberty within society. The various uses made of this distinction is an issue that goes beyond the scope of this article. I will conclude by saying a few words about one such use, with the hope of illustrating that the ambiguity of 'liberty' can be dispelled only with reference to different modes of human existence and the role played by institutions within them.

Let me revisit the subtleties of Hobbes' theory of liberty in Leviathan, where liberty is used in three different senses, with three different relationships to the institutional reality. First, liberty as the absence of external impediment of motion, where the restraint is physical and what is restrained or not are bodies in motion. This is the only sense of liberty that does not have anything to do with law. Both its existence and its restriction are independent of the institutional reality. My liberty in this first sense is completely unaffected by any lack of liberty in the other two senses. This is not liberty from the law since law is irrelevant to it.

The other two senses both involve man's relation to law, but in two different ways, one relating to the existence of it as an institution and the other to the workings of it as an institution. Natural liberty, which is synonymous with 'right', is the absence of obligation. It exists only in the state of nature. Indeed, abandoning our natural liberty by putting ourselves under obligation to a legislator is what leaving 


\section{LIBERTY AND LAW}

the state of nature amounts to. Our natural liberty not to be obligated is what we give up in the covenant that constructs the sovereign and the commonwealth. This is one sense in which to understand the formula 'liberty from the law': We are free when law does not exist.

When Hobbes says, in the famous quote, that liberty depends on the silence of the laws we are already in the commonwealth, under a legislator. Natural liberty is not there to be had. The third sense of liberty people either have or not in their capacity as subject to law. This is the other sense of 'liberty from the law': An absence of obligation, but not because there is no one who is owed obedience, but because that someone, who is owed obedience, has not spoken. This is a distinctly political form of liberty because it makes sense only in and given political society, where law does exist. A legislator that does not exist cannot be silent any more than it can speak.

This emphasises the constructive character of Hobbes' theory but also a more general point. The distinctly political form of liberty that subjects may enjoy can exist and be restricted only within and given a distinct form of social reality: It presupposes the existence of law as an institution. To be free from law in the sense that there is no one there with authority to make law for you, and to be free from law in the sense that the someone who does have such authority has left certain areas of life unregulated do not represent different degrees of freedom. They represent distinct forms of social existence, and within the respective domain of each being free means different things. 


\section{LENA HALLDENIUS}

\section{NOTES}

1. Throughout the discussion here $\mathrm{I}$, along with many other writers like Berlin (1969, p. 121) and Skinner, will treat the terms 'freedom' and 'liberty' as if they were interchangeable. According to Skinner 'nothing hangs on this difference of terminology' (1984, p. $194 n$ ), which of course is true only to the extent one does not in fact hang anything on it. Some do. On this, see Pitkin (1988) and Williams (2001) who treat 'liberty' as a distinctly political value. I see a merit in this distinction but do not pursue it here.

2. References to Leviathan are to Edwin Curley's 1994 edition and by chapter and paragraph number.

3. References to the Second Treatise of Government are to Peter Laslett's 1988 edition and by paragraph number.

4. Philip Pettit calls this the 'law-and-liberty test' (1993 p. 28f). I will add 'liberty under law' as a third category.

5. The proper signification of liberty is defined in Leviathan ch. xxi 1 and the liberty of subjects in paragraphs 5 and 6 of that chapter. See Quentin Skinner 'Hobbes on the Proper Signification of Liberty' in Skinner 2002 for a forceful analysis of Hobbes' theory of liberty, particularly in its relation to power or ability.

6. 'I am no longer free if someone can constrain my will' Rousseau A Discourse on Political Economy in The Basic Political Writings 1987, p. 116.

7. Positive freedom 'consists in being one's own master', which is said to imply - as a matter of historical circumstance - a bifurcated sense of the self, where self-mastery entails a 'higher', 'autonomous' rational self bringing the 'lower', 'heteronomous' unbridled self to heel. See Berlin 1969, p. 131f.

8. For fuller discussions see Halldenius 'Locke and the Non-arbitrary' (2003) and 'The Primacy of Right' (2007).

9. 'Liberty from the law' and 'liberty by the law' could be construed as expressing a difference between liberalism and republicanism. To be fair to these traditions of thought, however, they are both so diverse that such a simple distinction is less than informative. Within the republican tradition there are at least two strands of thought regarding liberty in political society. According to Quentin Skinner the significant difference between liberalism and republicanism is that in the republican view the liberty of an individual person cannot be assessed independently of the liberty of the community of which the citizen is a part (1984 p. 213). Skinner also claims (along with Philip Pettit, 1989 and 1993) that republican liberty is negative in the familiar sense of the word. If a free community is a community that governs itself - through its own citizens - and if the liberty of the individual citizen is dependent on this, then the liberty of the citizen will require political participation. Liberty as participation is traditionally conceived as positive. See also Skinner's Liberty Before Liberalism (1998). 


\section{LIBERTY AND LAW}

10. Locke refers to law as 'the direction of a free and intelligent Agent' in Second Treatise $\S 57$. Tapani Turkka kindly reminded me of this passage.

11. In 'Locke and the Non-arbitrary' (2003) I argue that consent does not play an independent part in Locke's theory of legitimacy. Consent is an expression of reason and as such is dependent on the ends of political power being upheld.

12. Remember that Hobbes proceeds from the opposite assumption - that men are by nature equal in strength - and that government is necessary because of equality, since the instability and danger that comes with everyone being a threat to everyone can be countered only be the construction of an irresistible power, which nature does not provide.

13. See Wollstonecraft A Vindication of the Rights of Men 1995 p. 7.

14. Richard Price invokes the same formula: 'Civil government [...] is an institution of human prudence $[. .$.$] for securing to the members of a community that liberty to which$ all have an equal right' (Price A Discourse on the Love of our Country in Political Writings 1991 p. 184). On Price's conception of liberty, see Additional Observations: 'Individuals in private life, while held under the power of masters, cannot be denominated free, however equitably and kindly they may be treated' (1991 p. 77) and Observations on the Nature of Civil Liberty: 'to be free is to be guided by one's own will: and to be guided by the will of another is the characteristic of servitude' (1991 p. 26).

15. I do not mean to say that 'liberty by the law' in itself requires representative government, only that it puts conditions on the form and reach of legitimate government, conditions that may be spelled out in various ways. For Wollstonecraft's spelling out of those conditions in the form of representative government, see The French Revolution 1989 pp. 35, 64, 212. On the need for a constitution accepted by the people and on the organization of government, pp. 53, 133, 165, 167, 186f. For Wollstonecraft the egalitarian demands of liberty extend not only to political and civil rights but also to property, thus making inequalities in all these areas political concerns.

16. 'I really think that women ought to have representatives, instead of being arbitrarily governed without having any direct share allowed them in the deliberations of government' Wollstonecraft A Vindication of the Rights of Woman 1995 p. 237.

17. 'Everything is what it is: liberty is liberty, not equality or fairness or justice or culture, or human happiness or a quiet conscience' (Berlin 1969 p. 125).

18. For the limits of the subjects' obligation - 'the things which, though commanded by the sovereign, he may nevertheless without injustice refuse to do' - see Leviathan ch. xxi 10-17. For the definition of peace, see ch. xiii 8.

19. The only source of obligation for Hobbes is an act of will.

20. 'Only a rational being has the power to act in accordance with his idea of laws - that is, in accordance with principles - and only so has he a will. Since reason is required in order to derive actions from laws, the will is nothing but practical reason.' Kant Groundwork of the Metaphysic of Morals 1964 p. 80. 


\section{LENA HALLDENIUS}

\section{REFERENCES}

Bentham, Jeremy 1843. On the Liberty of the Press, and Public Discussion. Jeremy Bentham to the Spanish People. Letter III. On the Liberty of Public Discussion in Free Meeting - Continuation from Letter II. In John Bowring (ed.) The Works of Jeremy Bentham Vol. 2. Edinburgh: W. Tait.

Berlin, Isaiah 1969. Four Essays on Liberty. Oxford: Oxford University Press.

Halldenius, Lena 2003. Locke and the Non-arbitrary. The European Journal of Political Theory, Vol. 2, Is. 3, 261-279.

Halldenius, Lena 2007. The Primacy of Right. On the Triad of Liberty, Equality, and Virtue in Wollstonecraft's Political Thought. The British Journal for the History of Philosophy, Vol. 15, Is. 1, 75-99.

Hobbes, Thomas 1994 [1651]. Leviathan. Edwin Curley (ed). Indianapolis: Hackett Publishing Company.

Kant, Immanuel 1964 [1785]. Groundwork of the Metaphysic of Morals. H. J. Paton (transl. and ed.). New York: Harper \& Row.

Kant, Immanuel 1996 [1797]. The Metaphysics of Morals. Mary Gregor (transl. and ed.). Cambridge: Cambridge University Press.

Locke, John 1988 [1689]. Two Treatises of Government. Peter Laslett (ed.). Cambridge: Cambridge University Press.

Pettit, Philip 1989. A Definition of Negative Liberty. Ratio NS, Vol. 2, Is. 2, 153-168.

Pettit, Philip 1993. Negative Liberty, Liberal and Republican. European Journal of Philosophy, Vol. 1, No. 1, 15-38.

Pitkin, Hanna Fenichel 1988. Are Freedom and Liberty Twins? Political Theory, Vol. 16, Is. 4, 523-552.

Price, Richard 1991 [1776, 1777, 1789]. Observations on the Nature of Civil Liberty, Additional Observations, and Discourse on the Love of our Country. In D. O. Thomas (ed.) Political Writings. Cambridge: Cambridge University Press.

Rousseau, Jean Jacques 1987 [1755, 1762]. A Discourse on Political Economy and On the Social Contract. In Donald A. Cress (transl. and ed.) The Basic Political Writings. Indianapolis/Cambridge: Hackett Publishing Company.

Skinner, Quentin 1984. The Idea of Negative Liberty: Philosophical and Historical Perspectives. In R. Rorty, J. B. Schneewind and Q. Skinner (eds.), Philosophy in History. Cambridge: Cambridge University Press, 193-221.

Skinner, Quentin 1998. Liberty Before Liberalism. Cambridge: Cambridge University Press.

Skinner, Quentin 2002. Visions of Politics. Volume III Hobbes and Civil Science. Cambridge: Cambridge University Press. 


\section{LIBERTY AND LAW}

Williams, Bernard 2001. From Freedom to Liberty: The Construction of a Political Value. Philosophy and Public Affairs, Vol. 30, Is. 1, 3-26.

Wollstonecraft, Mary 1989 [1794]. An Historical and Moral View of the Origin and Progress of the French Revolution and the Effect it has Produced in Europe. In J. Todd J and M. Butler (ed.) The Works of Mary Wollstonecraft Vol. 4. London: William Pickering.

Wollstonecraft, Mary 1995 [1790, 1792]. A Vindication of the Rights of Men and A Vindication of the Rights of Woman. Sylvana Tomaselli (ed.). Cambridge: Cambridge University Press. 